\author{
DEPARTMENT OF THE INTERIOR \\ UNITED STATES GEOLOGICAL SURVEY
}

PREPARED IN COOPERATION WITH THE COMMONWEALTH OF MASSACHUSETTS

DEPARTMENT OF PUBLIC WORKS

\title{
AEROMAGNETIC MAP OF THE HULL QUADRANGLE SUFFOLK, NORFOLK, AND PLYMOUTH COUNTIES MASSACHUSETTS
}

\author{
GEOPHYSICAL INVESTIGATIONS \\ MAP GP-678
}

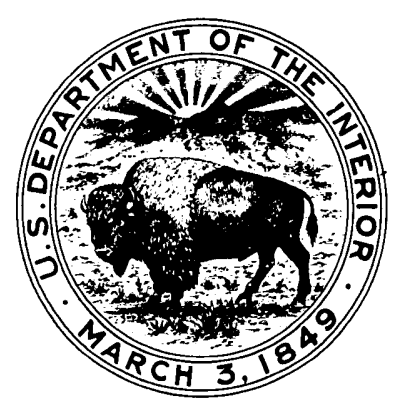

PUBLISHED BY THE U.S. GEOLOGICAL SURVEY 